\title{
Depth of application of a microgranule for precision sowing on the controlled release of nutrients, and the growth of maize plants in the initial stage of development
}

\author{
$\underline{\text { Natalia Matłok }}^{1}$, Józef Gorzelany ${ }^{2}$, Piotr Antos ${ }^{3}$, Maciej Balawejder ${ }^{4}$
}

1. Department of Food and Agriculture Production Engineering, University of Rzeszow, Poland, 35-601 Rzeszów, Zelwerowicza 4,nmatlok@ur.edu.pl

2. Department of Food and Agriculture Production Engineering, University of Rzeszow, Poland, 35-601 Rzeszów, Zelwerowicza 4, gorzelan@ur.edu.pl

3. Department of Computer Engineering in Management, Rzeszow University of Technology, Poland, 35-959

Rzeszów, Aleja Powstańców Warszawy 12, p.antos@prz.edu.pl

4. Department of Chemistry and Food Technology, University of Rzeszow, Poland, 35-601 Rzeszów, Ćwiklińskiej

1a, maciejb@ur.edu.pl

Abstract- The manuscript presents the results of vase experiments on the determination of the depth impact of soil microgranulate application for precision sowing on the growth of maize plants in the initial stage of development. Multi-component granule used in the experiment characterized by the controlled release of ingredients was made on the basis of an alternative source of a phosphate in accordance with the patent application No. P.429318.

Keywords - alternative raw material, phosphorus, precision fertilization, soil-applied microgranula, maize

\section{Introduction}

The innovative simplified technology of maize cultivation consists of the utilization of a cultivating and seeding aggregate, thanks to which seed sowing is performed at the same time as a deep precise application of fertilizer to cultivated soil [Ochal i in., 2015].

\section{Aim and scope}

The purpose of the pot experiments was to determine the effect of the depth of application for precision sowing of microgranules developed on the basis of an alternative source of phosphorus originating from thermally processed bone waste (patent application No. P. 429318) for the growth and development of corn at the initial stage of development.

\section{Methodology}

Table 1. Composition of microgranules for precision sowing

\begin{tabular}{|c|c|c|c|c|c|c|c|c|}
\hline \multicolumn{10}{|c|}{ Content of makro- and mikroelements } \\
\hline $\mathrm{P}_{2} \mathrm{O}_{5}$ & $\mathrm{~K}_{2} \mathrm{O}$ & $\mathrm{CaO}$ & $\mathrm{MgO}$ & $\mathrm{Na}_{2} \mathrm{O}$ & $\mathrm{Mn}$ & $\mathrm{Fe}$ & $\mathrm{Cu}$ & $\mathrm{Zn}$ \\
\hline $\begin{array}{c}314,0 \\
\mathrm{~g} \cdot \mathrm{kg}^{-1}\end{array}$ & $\begin{array}{c}42,3 \\
\mathrm{~g} \cdot \mathrm{kg}^{-1}\end{array}$ & $\begin{array}{c}663,1 \\
\mathrm{~g} \cdot \mathrm{kg}^{-1}\end{array}$ & $\begin{array}{c}240,3 \\
\mathrm{~g} \cdot \mathrm{kg}^{-1}\end{array}$ & $\begin{array}{c}5,4 \\
\mathrm{~g} \cdot \mathrm{kg}^{-1}\end{array}$ & $\begin{array}{c}6,5 \\
\mathrm{mg} \cdot \mathrm{kg}^{-1}\end{array}$ & $\begin{array}{c}1 \\
\mathrm{mg} \cdot \mathrm{kg}^{-1}\end{array}$ & $\begin{array}{c}3,2 \\
\mathrm{mg} \cdot \mathrm{kg}^{-1}\end{array}$ & $\begin{array}{c}0,8 \\
\mathrm{mg} \cdot \mathrm{kg}^{-1}\end{array}$ \\
\hline
\end{tabular}

The pot experiments were carried out under strict conditions in the vegetation greenhouse. Standardized soil, a mixture of sand and acidified peat with a $\mathrm{pH}$ of 5.5-6.5 in the ratio of 7: 1, was used in the experiment and certified maize seeds of the variety Farm Gigant $(\mathrm{MTZ}=264 \mathrm{~g})$ were utilized. The developed microgranule (table 1) for precision sowing at a dose of $30 \mathrm{~kg} \cdot$ ha- 1 was applied at the depth of: 2, 4, 6, 8 and $10 \mathrm{~cm}$ in relation to the kernel in the Fix system. The experiment was carried out at a constant soil moisture of $50 \%$ PPW. 


\section{Conclusions}

Based on the pot experiments on the depth of application of microgranules for precision sowing with controlled release of components, it was found that the highest growth and development of maize plants occurred in a variant in which the fertilizer was applied at a depth of $2 \mathrm{~cm}$ to the kernel. The location of microgranules at a depth of $2 \mathrm{~cm}$ from the kernel resulted in obtaining the highest parameters of biometric traits of maize plants in the 6th week of sowing (Fig. 1).
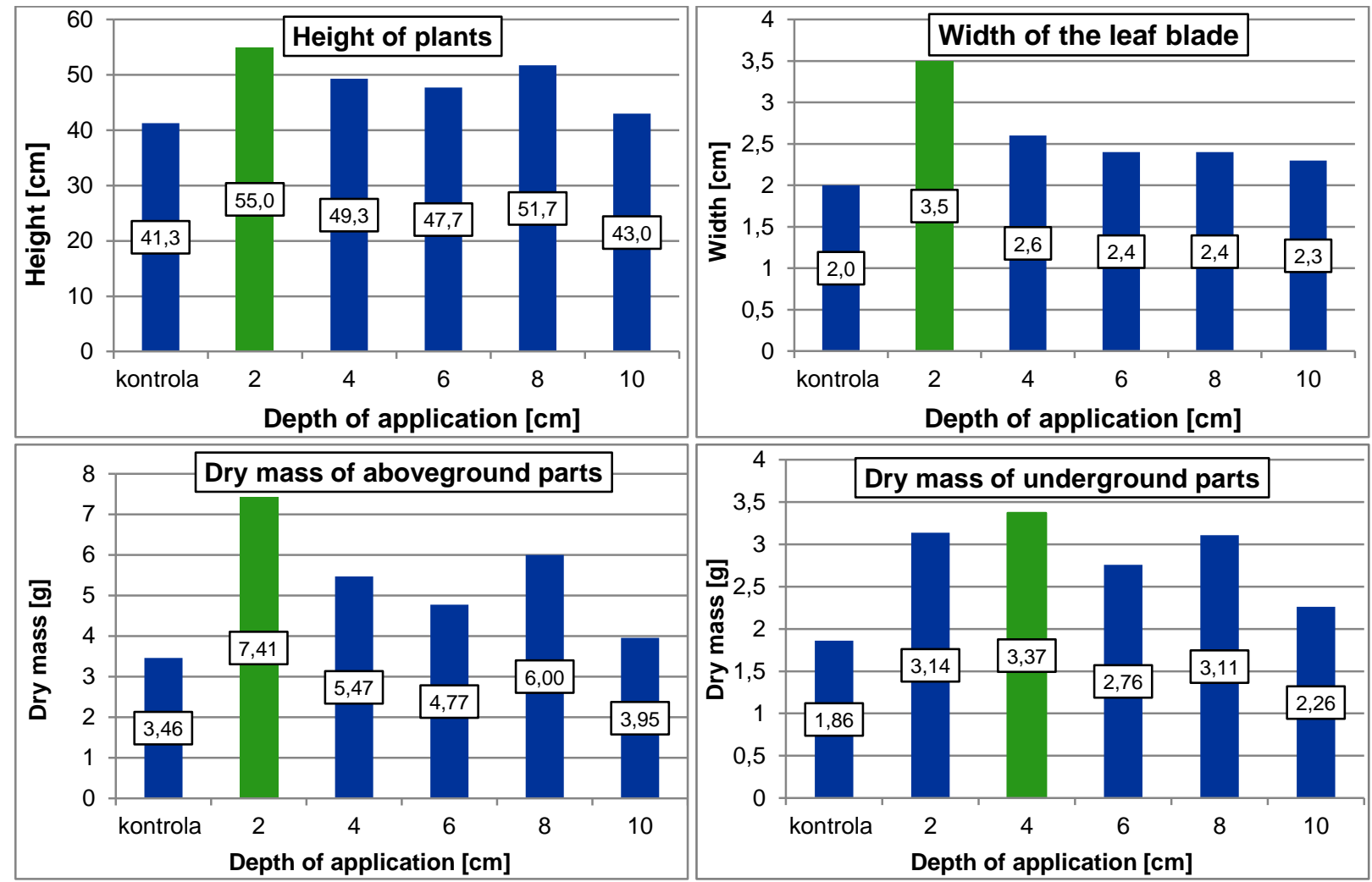

Fig.1. Biometric features of maize plants depending on the depth of application of the fertilizer

\section{Summary}

The application of a multi-component fertilizer with a controlled release of ingredients at a depth of $2 \mathrm{~cm}$ in relation to the kernel, developed on the basis of an alternative source of phosphate, results in the best growth and development of maize plants in the first 6 weeks of sowing.

\section{Thanks}

The research was carried out as part of the project "Development of innovative fertilizers on the basis of an alternative source of raw material" No. BIOSTRATEG1 / 270963 // 6 / NCBR / 2015 co-financed from public funds at the disposal of the National Center for Research and Development under the "Environment, Agriculture and Forestry" Program - BIOSTRATEG.

\section{Literature}

[1] Ochal P., Jadczyszyn T., Jurga B., „Rozwój systemu korzeniowego kukurydzy w zależności od umieszczenia nawozu w glebie”, Polish Journal of Agronomy, 23, s.74$81,2015$. 